\title{
Pollution et lutte contre la pollution urbaine en Europe aux XIXe et XXe siècles
}

\section{(2) OpenEdition}

Journals

Édition électronique

URL : https://journals.openedition.org/ch/71

DOI : $10.4000 /$ ch.71

ISSN : 1777-5264

Éditeur

Comité historique du Centre-Est

\section{Édition imprimée}

Date de publication : 1 janvier 2000

ISSN : 0008-008X

\section{Référence électronique}

" Pollution et lutte contre la pollution urbaine en Europe aux XIXe et XXe siècles », Cahiers d'histoire [En ligne], 45-1 | 2000, mis en ligne le, consulté le 28 juin 2022. URL : http://journals.openedition.org/ch/ 71 ; DOI : https://doi.org/10.4000/ch.71

Ce document a été généré automatiquement le 29 septembre 2020

(c) Tous droits réservés 


\title{
Pollution et lutte contre la pollution urbaine en Europe aux XIXe et XXe siècles
}

\author{
Rencontres internationales \\ pour une histoire de l'environnement \\ Premières journées, \\ Clermont-Ferrand, 4, 5 et 6 mai 2000 \\ POLLUTION \\ ET LUTTE CONTRE LA POLLUTION URBAINE \\ EN EUROPE AUX XIX ${ }^{\mathrm{e}}$ et XX $\mathrm{X}^{\mathrm{e}}$ SIÈCLES
}

Programme

Jeudi 4 mai 2000

14 h00 : Ouverture des Rencontres

1ère séance : $\mathrm{L}$ 'invention d'un problème politique : la pollution

14h15-15h00 : communications

De la souillure à la pollution, un essai d'interprétation des origines du concept de pollution The Dialectics of Dirt

Polluer et payer. Les prémices de la lutte contre la pollution dans quelques villes belges des XVIIIe et XIXe siècles

15h00-15h45 : discussion

16h15-17h00 : communications 
"Waldsterben ". The Construction and Deconstruction of an environmental problem

Entre morale et politique : l'invention du " Ministère de l'impossible "

Cultures environnementales et pollution

17h00-17h45 : discussion

18h00-22h30 (optionnel)

Vendredi 5 mai 2000

2e séance : Pollution de l'eau, pollution de l'air

9h00-9h45 : communications

L'invention des eaux usées : l'assainissement de Paris (1780-1930)

The perception of the water pollution problem in the Netherlands (19th and early 20th century)

Water pollution in Italy, the failure of the hygienic approach (1890-1960)

9h45-10h30 : discussion

\section{1h00-11h45 : communications}

The historical determinants of environmental concern: the problem of atmospheric pollution in late nineteenth and early twientieth century London

A look into the Black box: why air pollution control was undisputed in interwar Germany

Pollution caused by traffic and transport: public intervention and debates. The example of Berlin and other German cities (1900-1939)

11h45-12h30 : discussion

3e séance : Ville et industrie, quelle cohabitation?

14h15-15h00 : communications

Institutions et services en charge de la pollution à la fin du XIX siècle. L'exemple grenoblois (1870-1914)

Odeurs, fumées et écoulements putrides : les pollutions de l'industrie gazière au XIXe siècle Modifications du paysage et esprit industrialiste : les autorités municipales face au risque industriel (Grenoble, XIXe siècle)

15h00-15h45 : discussion

16h15-17h00 : communications

Urban industrial policy (Germany, 1890-1930)

Un siècle de cohabitation habitat-industrie dans la banlieue nord-ouest de Paris (1860-1960)

Activités humaines et ressources naturelles à Naples au XXe siècle : le cas du complexe industriel de Bagnoli

17h00-17h45 : discussion

18h00-20h00 (optionnel) : circuit en car 
Samedi 6 mai 2000

4e séance : Citoyens et citoyennes contre la pollution

9h.00-9h45 : communications

Civil movements for the urban green space. The case of the city Leipzig in the Sd Imperial Age Women and the environmental protest in Germany after 1945

Les sociétés de pêche : sensibilité, argumentaire et influence politique (France, XIXe et XXe siècles)

9h45-10h30 : discussion

\section{1h00-11h45 : communications}

The emergence and development of the environmental movement in Greece

Environmentalists, Citizens and workers: the struggle against Oil Industry Pollution in the San Francisco Bay Area

Mouvement sociaux et politique routière dans la Grande-Bretagne des années 1990

11h45-12h30 : discussion

12h30-13h00 : bilan des travaux et perspectives

Responsabilité scientifique :

Renseignements : 